\title{
DINAMIKA POLITIK SEPULUH TAHUN PERDAMAIAN DI ACEH (Analisis Politik Kawasan Pesisir Timur Aceh)
}

\author{
Usman \\ Program Studi Pendidikan Pancasila dan Kewarganegaraan, FKIP, Universitas Abulyatama \\ Jl. Blang Bintang Lama Km 8,5 Lampoh Keude Aceh Besar \\ email: usman@abulyatama.ac.id
}

\begin{abstract}
The aim of this study is to find out the situation, condition, and politic impact towards Acehnese society in ten years after reconciliation. The qualitative research is used in this study which the result to create a systemic, factual, and accurate description of the facts, characteristics as well as the related phenomena which is being investigation. The collecting data, the researcher used interview and field observation in Lhoksemawe, North Aceh, and Bireun. The result found that the political dominance in the East Coast Aceh is still controlled by Gerakan Aceh Merdeka which is affecting the political policies between Central Government and Aceh Government. For instance, it emerge the major conflicts within Gerakan Aceh Merdeka, such as Din Minimi, and political party rivalry. This political dynamics phenomena also affects the East Coast society life, such as political violence, intimidation, terror, and other political violences
\end{abstract}

Key words: Political Dynamics, Reconciliation, Political Conflict, Election

\begin{abstract}
Abstrak: Tujuan penelitian ini untuk mengetahui situasi, kondisi dan dampak politik yang terjadi terhadap masyarakat Aceh sepuluh tahun perdamaian. Adapun metode dalam penelitian ini menggunakan pendekatan jenis penelitian deskriptif kualitatif yang hasilnya untuk membuat gambaran secara sistematis, faktual dan akurat mengenai fakta-fakta, sifat-sifat serta berhubungan antara fenomena yang sedang diteliti. Melalui teknik pengumpulan data, seperti metode wawancara dan observasi lapangan di Kota Lhokseumawe, Aceh Utara dan Bireun. Hasil penelitian ini adalah dominasi politik di kawasan pesisir timur Aceh masih dikuasai oleh Gerakan Aceh Merdeka, sehingga mempengaruhi kebijakan-kebijakan politik pemerintah pusat dan Aceh, munculnya pertikaian besar dalam internal eks Gerakan Aceh Merdeka, seperti permasalahan Din Minimi dan persaingan partai politik. Fenomena dinamika politik berdampak juga terhadap kehidupan masyarakat kawasan lintas timur yaitu kekerasan politik, intimidasi, teror dan kekerasan politik lainnya.
\end{abstract}

\section{Kata Kunci : Dinamika Politik, Perdamaian, Konflik Politik, Pilkada}

Dinamika dalam sebuah kelompok sering ditentukan oleh orang-orang yang berpengaruh di dalamnya. Dinamika juga dapat diartikan sebagai suatu proses pergerakan yang mengalami perubahan seiring dengan berjalannya waktu. Gerak politik dapat terjadi dimana saja, termasuk di daerah Aceh, banyak aspek yang dapat mempercepat proses terjadinya, seperti aspek sosial, budaya, politik dan ekonomi. Peninjauan dinamika melalui aspek ilmu politik memberikan pemahaman mengenai situasi dan kondisi politik yang terjadi.

Perpolitikan di Aceh pada umumnya dikaitkan dengan upaya penyelesaian konflik yang terjadi sebelum perdamaian, dan dalam catatan sejarahnya, daerah Aceh dianggap termasuk dalam 
daerah yang tidak pernah lepas dari konflik, Pasca kemerdekaan Indonesia, konflik antara Aceh dan Pemerintah Pusat pertama kali terjadi pada saat gerakan Darul Islam (DI/TII) Pimpinan Teungku Daud Beureueh diproklamirkan pada tahun 1953 (Usman, 2003:124). Konflik antara Aceh dengan Pemerintah Pusat pasca kemerdekaan Indonesia mereda, dengan diberikannya hak khusus oleh Pemerintah Pusat untuk Aceh berupa otomomi dalam bidang Agama, Adat, dan Pendidikan sehingga gencatan senjata berhasil dilakukan pada 1957-1959 (Majalah Aceh Kita, Agustus 2005:16).

Diplomasi menjadi alternatif terbaik dalam mengakhiri konflik yang terjadi antar kelompok untuk mencapai perdamaian dari suatu kesepakatan yang telah disepakati bersama. Merujuk kepada perdamaian yang tercapai pada era Teungku Daud Beureueh dengan Pemerintah Pusat, maka Nota Kesepahaman atau MoU (Memorandum of Understanding) yang dilaksanakan pada 15 Agustus 2005 berlokasi di Helsinki, Finlandia menjadi akhir dari konflik yang terjadi antara Aceh dengan Pemerintah Pusat yang dimulai sejak 4 Desember 1976 di bawah kepemimpinan Hasan Tiro.

Perundingan antara Pemerintah Indonesia dan GAM kali ini difasilitasi oleh Martti Ahtisaari, mantan Presiden Finlandia dan menjabat sebagai Ketua Dewan Direktur Crisis Management Initiative (CMI). Perundingan ini menghasilkan Memorandum of Understanding (MoU) yang memberikan keleluasaan bagi Aceh untuk beberapa hal, yaitu: Pertama, Aceh memiliki identitas kultural dengan penerapan Syari'at Islam dan Lembaga Wali Nanggroe. Kedua, Aceh mendapat keadilan ekonomi yaitu pembagian hasil minyak bumi dan gas sebesar 70 persen. Ketiga, rakyat Aceh mendapatkan hak politiknya melalui pembentukan partai politik lokal (parlok). Ketiga butir inilah yang kemudian diatur dalam UndangUndang Nomor 11 tahun 2006 tentang Pemerintahan Aceh. Selain hal tersebut di atas terdapat pula permasalahan lainnya, seperti keinginan bagi kawasan lintas timur, lintas tengah, dan lintas barat agar dapat dilakukannya pemekaran Kabupaten di Provinsi Aceh, serta masalah Din Minimi sebagai eks GAM.

Perdamaian merupakan hasil akhir dari konflik dan menjadi bagian dari Hak Asasi Manusia (HAM). Semenjak disahkannya Nota Kesepahaman atau MoU (Memorandum of Understanding) Helsinki, Finlandia. Tentunya perdamaian yang telah dirasakan sepuuh tahun terakhir diharapkan banyak memberikan perubahan kearah yang lebih baik terhadap kondisi politik dan sosial masyarakat dengan penerapan strategi yang efektif oleh semua stakeholder, strategi yang efektif dapat dicapai melalui pengunaan teknologi, modal, keterampilan dan pemberdayaan kelembagaan untuk tetap terjaganya perdamaian kondusif (manajemen penanganan konflik politik serta tindak kekerasan) yang terjadi selama perdamaian di Aceh pada kawasan lintas pesisir timur.

Dinamika politik di Aceh menjadi pendorong tumbuh berkembangnya demokrasi. Untuk itu tidak berlebihan dikatakan bahwa kegiatan penelitian ini sangat penting untuk dilakukan. Untuk mengetahui dinamika politik, berupa situasi, kondisi politik yang terjadi dan dampaknya terhadap masyarakat di Aceh, khususnya, kawasan lintas timur. Hasil penelitian kemudian dirumuskan 
dalam analisis yang dibatasi dalam beberapa pokok permasalahan yaitu: dinamika politik yang terjadi selama kurun waktu sepuluh tahun perdamaian dan dampak terhadap masyarakat.

\section{METODE PENELITIAN}

Metode penelitian ini menggunakan metode pengumpulan data dengan wawancara dan observasi lapangan. Pendekatan yang digunakan dalam penelitian ini adalah pendekatan deskriptif kualitatif. Jenis dan sumber data yang dikumpulkan adalah data primer. Data yang diperoleh selanjutnya dianalisis sesuai dengan data yang diperoleh. Data yang bersifat kualitatif dianalisis secara deskriptif untuk memberikan gambaran tentang keadaan politik atau kondisi masyarakat terkait dengan dinamika politik sepuluh tahun perdamaian di Aceh.

Lokasi penelitian ini yaitu Bireuen, Lhokseumawe, dan Aceh Utara. Pemilihan subjek penelitian dilakukan dengan teknik purposive random sampling. Teknik ini digunakan untuk menyesuaikan dengan tujuan penelitian, sehingga subjek yang dipilih diharapkan dapat menjadi sumber data yang komunikatif, transparan serta representatif. Adapun subjek dalam penelitian ini adalah beberapa Partai Politik (Parlok dan Parnas), Akademisi, Tokoh Agama dan Tokoh Pemuda.

\section{TINJAUAN PUSTAKA}

Mengenai dinamika politik, Gaffar (2004:99) mengemukakan: Dinamika politik pada tingkatan lokal merupakan penjabaran dari berbagai macam SARA (Suku, Adat, Ras dan Agama) yang ada di Indonesia. Hal ini yang membuat kebanyakan orang kesulitan menentukan identitas politik ataupun budaya politik Indonesia. Jika ada orang yang berhasil mengidentifikasi budaya politik Indonesia, kiranya tak mungkin lepas dari pertimbangan realitas politik lokal yang ada.

Dilihat dari perspektif antropologis, masyarakat Aceh juga dikenal dengan berbagai suku, seperti suku Aceh, Gayo, Alas, Tamiang, Simeulue, Kluet, Aneuk Jame, dan lain-lain yang termasuk ke dalam golongan rumpun melayu. Adat dan agama merupakan suatu hal yang tidak bisa terpisahkan dalam kehidupan masyarakat Aceh, seperti zat dengan sifat. Mayoritas masyarakat Aceh beragama Islam, dan sangat menunjung tinggi adat istiadat, sehingga dilihat dari perspektif hukumnya, pengaturan kebijakan perihal adat dan agama (Lembaga Wali Nanggroe dan penerapan Syari'at Islam) menjadi perwujudan untuk tetap menegakkan Syari'at Islam secara kaffah dalam membangun Aceh kearah yang lebih baik, sebagaimana terdapat di dalam UndangUndang No. 11 tahun 2006 tentang Pemerintahan Aceh.

Dengan lahirnya Undang-Undang Nomor 11 Tahun 2006 tentang Pemerintahan Aceh (UUPA) sebagai wujud kesepakatan damai antara Pemerintah Republik Indonesia dan Gerakan Aceh Merdeka (GAM) pada tanggal 15 Agustus 2005 di Helsinki, telah memberi peluang yang sangat besar untuk mewujudkan kesejahteraan rakyat Aceh. UUPA idealnya menjadi pondasi bagi pelaksanaan pembangunan Aceh ke depan. Pelaksanaan pembangunan tersebut dilakukan melalui penerapan sistem desentralisasi.

Menurut Henry Maddick (Nurcholis, 2005:9) "Desentralisasi adalah penyerahan kekuasaan secara hukum untuk menangani bidang- 
bidang/fungsi-fungsi tertentu kepada daerah otonom".

Desentralisasi dapat juga dianggap sebagai suatu penyerahan perancanaan, pembuatan keputusan, atau kewenangan administratif dari pemerintah pusat terhadap pemerintah daerah atau organisasi non pemerintah/lembaga swadaya masyarakat, organisasi wilayah, satuan administratif daerah, organisasi semi otonom sebagaimana dikemukakan Rondinelli (Nurcholis, 2005:9).

Dinamika politik yang terjadi di kawasan lintas timur Aceh turut dipengaruhi dengan faktor tingginya tingkat kemiskinan. Menurut teori konservatif, kemiskinan berasal dari karakteristik khas orang-orang miskin. Seseorang menjadi miskin bukan hanya karena masalah mental atau tiadanya kesempatan untuk sejahtera, tetapi juga karena adanya perspektif masyarakat yang menyisihkan dan memiskinkan orang.

\section{HASIL DAN PEMBAHASAN}

Mengenai kecenderungan politik, O'leary (2000:790) berpendapat: Bahwa secara garis besar, politik cenderung terbagi dua kubu: Pertama, high politics (politik tinggi), yaitu yang mempelajari perilaku politik para pembuat keputusan elit; mereka percaya bahwa kepribadian dan mekanisasi para elit politik adalah kunci pembuat sejarah. Mereka juga percaya bahwa perluasan kekuasaan dan kepentingan diri dapat menjelaskan perilaku sebagian besar kaum elit. Kedua, low politics (politik bawah), atau politik dari bawah. Mereka percaya bahwa perilaku politik massa memberikan kunci untuk menjelaskan episodeepisode politik utama seperti halnya beberapa revolusi yang terjadi. Selain itu bagi mereka kharisma, plot, maupun blunder para pemimpin kurang begitu penting dibanding dengan perubahan nilai-nilai kepentingan dan tindakan kolektivitas.

Nota Kesepahaman MoU atau (Memorandum of Understanding) Helsinki, Finlandia yang disepakati pada 15 Agustus 2005 merupakan high politics (politik tinggi) dan menjadi sejarah untuk mengakhiri konflik antara Gerakan Aceh Merdeka dengan Pemerintah Pusat serta menciptakan perdamaian di Aceh dengan mekanisme perpolitikan dari elit politik yang didukung juga oleh masyarakat internaional sehingga damai di Aceh dapat terselenggarakan. Untuk low politics (politik bawah), misalnya terjadinya unjuk rasa (demonstrasi) yang dilakukan oleh masyarakat terhadap Pemerintahan dalam menuntut keadilan supaya terciptanya kesejahteraan melalui kebijakan-kebijakan yang dianggap dapat memberikan perubahan hidup yang lebih baik, semisal: penurunan harga bahan bakar minyak dan sembilan bahan pokok (sembako) untuk menciptakan kestabilan ekonomi bagi masyarakat kalangan bawah. Budiardjo (2008:409) mengemukakan:

Potensi konflik selalu ada di setiap masyarakat, apalagi di masyarakat yang bersifat heterogen, apakah dari segi etnis (suku bangsa), sosial-ekonomi, ataupun agama. Setiap perbedaan tersebut menyimpan potensi konflik. Apabila keanekaragaman itu terjadi di negara yang menganut paham demokrasi, persaingan dan perbedaan pendapat dianggap hal yang wajar dan mendapat tempat. Akan tetapi di dalam negara sifatnya, potensi pertentangan lebih besar dan 
dengan mudah mengundang konflik.

Kawasan lintas timur Aceh merupakan kawasan yang sering mengalami konflik yang lebih tinggi terjadi dibandingkan dengan kawasan lintas barat serta tengah Aceh, dengan struktur keadaan kawasannya yang berbukit-bukit serta landai dengan jumlah penduduknya yang padat dan mayoritas beragama Islam. Berakhirnya konflik dan timbulnya perdamaian di Aceh menjadi suatu anugerah yang dirasakan kembali oleh masyarakat, sehingga perdamaian tersebut perlu tetap terjaga.

Konflik selalu terjadi di masyarakat yang menganut paham demokrasi, sebagaimana yang terjadi di Negara Indonesia, terutama terhadap masyarakat yang bersifat heterogen termasuk masyarakat Aceh dalam kawasan lintas timur, tengah, dan barat. sehingga diperlukannya pendekatan dan strategi pembangunan perdamaian pasca-konflik secara khusus, bukan hanya untuk mencegah agar konflik tidak kembali muncul ke permukaan tetapi juga untuk mengkonsolidasikan perdamaian menuju tercapainya pembangunan dan perdamaian berkelanjutan.

Konflik yang telah terlanjur terjadi seperti konflik vertikal antara Pemerintah Pusat dengan GAM sebisa mungkin harus dapat dikelola dengan baik karena akibat yang ditimbulkan oleh konflik akan memberi akibat negatif dalam jangka panjang. Dalam konteks kehidupan bermasyarakat dan bernegara efek sampingnya dapat berupa kacaunya suasana/keadaan, gangguan keamanan atau terputusnya hubungan antar manusia bahkan menghalangi tercapainya tujuan bernegara itu sendiri yaitu kemakmuran bagi seluruh rakyat.

Robbins dan Judge (2007), membagi cara penanganan konflik ke dalam lima model: Pertama, Kompetisi. Gaya ini bersikap tidak kooperatif tetapi asertif (unsur memaksa), bekerja dengan cara menentang keinginan pihak lain, berjuang untuk mendominasi dalam suatu situasi "menang-atau-kalah", dan atau memaksakan segala sesuatu agar sesuai dengan kesimpulan tertentu dengan menggunakan kekuasaan yang ada. Kedua, Kolaborasi (kerjasama). Gaya ini bersikap kooperatif dan asertif, berupaya untuk mencapai kepuasan benar-benar setiap pihak yang berkepentingan dengan jalan bekerja melalui perbedaan-perbedaan yang ada, mencari dan memecahkan masalah sedemikian rupa sehingga setiap orang mencapai keuntungan sebagai hasilnya. Ketiga, Menghindar. Gaya ini bersikap tidak kooperatif dan tidak asertif, menarik diri dari situasi yang berkembang dan atau bersikap netral dalam segala macam "cuaca". Keempat, Akomodatif. Ketika salah satu pihak berusaha menyenangkan hati lawannya, pihak tersebut kiranya akan bersedia menempatkan kepentingan lawan di atas kepentingannya sendiri. Dengan kata lain agar hubungan tetap terpelihara, salah satu pihak bersedia berkorban. Kelima, Kompromis. Ketika masing-masing pihak yang berkonflik berusaha mengalah dalam satu atau lain hal, terjadilah tindakan berbagi, yang mendatangkan kompromi. Dalam model kompromi ini, tidak jelas siapa yang menang dan siapa yang kalah.

Undang-Undang Pemerintah Aceh (UUPA) yang ditetapkan pada tanggal 1 Agustus 2006 telah merubah paradigma tatanan sosial kemasyarakatan di Aceh dan merupakan tonggak sejarah perjalanan bangsa Indonesia, khususnya masyarakat Aceh baik kawasan lintas timur, tengah, maupun barat. 
UUPA ini merupakan produk perundang-undangan yang menjadi pedoman bagi penyelenggaraan pemerintahan di Aceh pasca penandatanganan MoU Helsinki. UUPA diharapkan dapat menumbuhkan masyarakat Aceh baru yang mampu mewujudkan perdamaian menyeluruh dan berkelanjutan guna menciptakan kesejahteraan masyarakat Aceh.

Masyarakat madani atau civil society mempunyai sepuluh ciri khusus, kesepuluh ciri masyarakat madani tersebut yaitu: (1) Menjunjung tinggi nilai-nilai norma, dan hukum adalah hal pokok yang harus dimiliki oleh masyarakat madani. (2) Beradab artinya masyarakat yang mempunyai peradaban yang tinggi. (3) Keterbukaan dapat diartikan mengedepankan kesederajatan dan transparasi ini khusunya bagi pemerintah. (4) Ruang publik yang bebas diartikan sebagai wilayah di mana masyarakat sebagai warga negara memiliki akses penuh terhadap setiap kegiatan publik. (5) Demokratisasi, adalah masyarakat sosial berkaitan dengan wacana kritik rasional masyarakat yang secara ekspisit mensyaratkan tumbuhnya demokrasi. Toleransi, adalah kesediaan individu untuk menerima pandangan-pandangan politik dan sikap sosial yang berbeda beda. (7) Pluralisme, adalah sikap mengakui dan menerima kenyataan disertai sikap tulus bahwa masyarakat itu majemuk. (8) Keadilan sosial, keadilan yang dimaksud adalah keseimbangan dan pembagian yang proporsional antara hak dan kewajiban setiap warga dan negara. (9) Partisipasi sosial merupakan awal yang baik bagi terciptanya masyarakat madani. Partisipasi sosial yang bersih dapat terjadi apabila tersedia iklim yang memungkinkan otonomi individu terjaga. (10) Supermasi hukum, merupakan jaminan terciptanya keadilan, keadilan harus diposisikan secara netral, artinya tidak ada pengecualian untuk memperoleh kebenaran di atas hukum.

Pada 25 April 2009, Komisi Pemilihan Umum (KPU) menetapkan hasil rekapitulasi perolehan suara nasional Pilpres 2009 yang telah diselenggarakan pada 22 - 23 Juli 2009. Berikut merupakan hasil suara Pilpres 2009 (www.kpu.go.id) yang telah ditetapkan sebagai berikut.

Tabel 1. Rekapitulasi Hasil Suara Pemilu Presiden dan Wakil Presiden 2009

\begin{tabular}{|c|c|c|c|}
\hline No & $\begin{array}{l}\text { Pasangan } \\
\text { Calon }\end{array}$ & $\begin{array}{l}\text { Jumlah } \\
\text { Suara }\end{array}$ & $\begin{array}{l}\text { Persentase } \\
\text { Suara }\end{array}$ \\
\hline 1 & $\begin{array}{l}\text { Megawati- } \\
\text { Prabowo }\end{array}$ & 32.548 .105 & $26,79 \%$ \\
\hline 2 & $\begin{array}{l}\text { SBY- } \\
\text { Budiono }\end{array}$ & 73.874 .562 & $60,80 \%$ \\
\hline 3 & JK-Wiranto & 15.081 .814 & $12,41 \%$ \\
\hline \multicolumn{2}{|r|}{ Jumlah } & 121.504 .481 & $100,00 \%$ \\
\hline
\end{tabular}

\begin{tabular}{|lr|r|}
\hline \multicolumn{2}{|c|}{ Jumlah Suara Sah } & 121.504 .481 \\
\hline $\begin{array}{l}\text { Jumlah Suara Tidak } \\
\text { Sah }\end{array}$ & 6.479 .174 \\
\hline $\begin{array}{c}\text { Jumlah Suara } \\
\text { Peserta }\end{array}$ & 127.983 .655 \\
\hline $\begin{array}{c}\text { Jumlah } \\
\text { Pemilih }\end{array}$ & Suara & 171.068 .667 \\
\hline
\end{tabular}

sumber:http://wartasejarah.blogspot.com/2013/10/ pemilihan-presiden-2009.html 


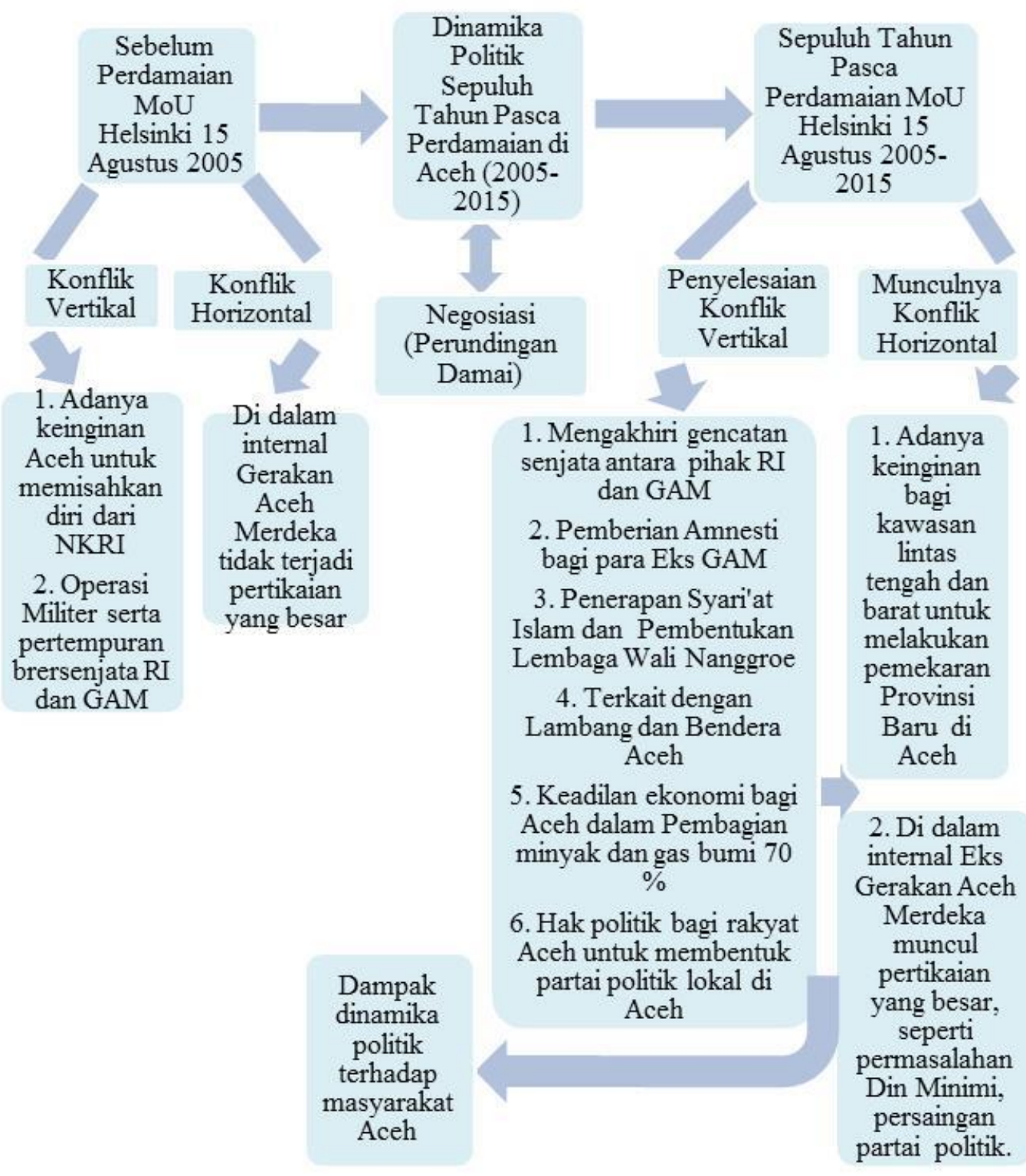

Gambar 1 Pola Dinamika Politik Sepuluh Tahun Perdamaian di Aceh 
Hasil penelusuran dari Atjehpost.co, dikemukakan bahwa Partai Gerindra kurang mendapatkan sambutan di Aceh pada pelaksanaan Pemilu 2009. Ini dibuktikan dengan tidak adanya satupun kader Gerindra yang lolos ke DPR RI dari Aceh pada tahun 2009, demikian pula dengan DPR Aceh. Dalam Pemilu 2009 yang telah dilaksanakan telihat bahwa Partai Demokrat meraih persentase hasil suara tertinggi.

Berdasarkan rekapitulasi Komisi Pemilihan Umum (KPU) yang tidak dihadiri saksi dari Megawati-Prabowo dan JK-Wiranto, dikemukakan bahwa SBY-Boediono unggul dalam perolehan suara terbanyak di 29 Provinsi. MegawatiPrabowo hanya memperoleh suara terbanyak di Provinsi Bali, sementara JK-Wiranto memperoleh suara terbanyak di Provinsi Sulawesi Selatan, Sulawesi Tenggara, dan Gorontalo. Dan kemenangan SBY-Boediono tersebut lebih dari 20 persen. Selanjutnya Komisi Pemilihan Umum (KPU) menetapkan pasangan Susilo Bambang Yudhoyono-Boediono sebagai Presiden dan Wakil Presiden terpilih tahun 2009. Penetapan tersebut terdapat dalam Surat Keputusan KPU Nomor 373/kpts/KPU/2009 tanggal 18 Agustus 2009 serta ditandatangani oleh Ketua KPU Abdul Hafiz Anshary. Sekjen KPU Suripto Bambang Setyadi yang membacakan SK KPU Nomor 373/2009 dalam Rapat Pleno Terbuka KPU, sebagai berikut: "Menetapkan Susilo Bambang Yudhoyono dan Boediono sebagai Presiden dan Wakil Presiden terpilih hasil Pemilu 2009 periode 2009-2014".

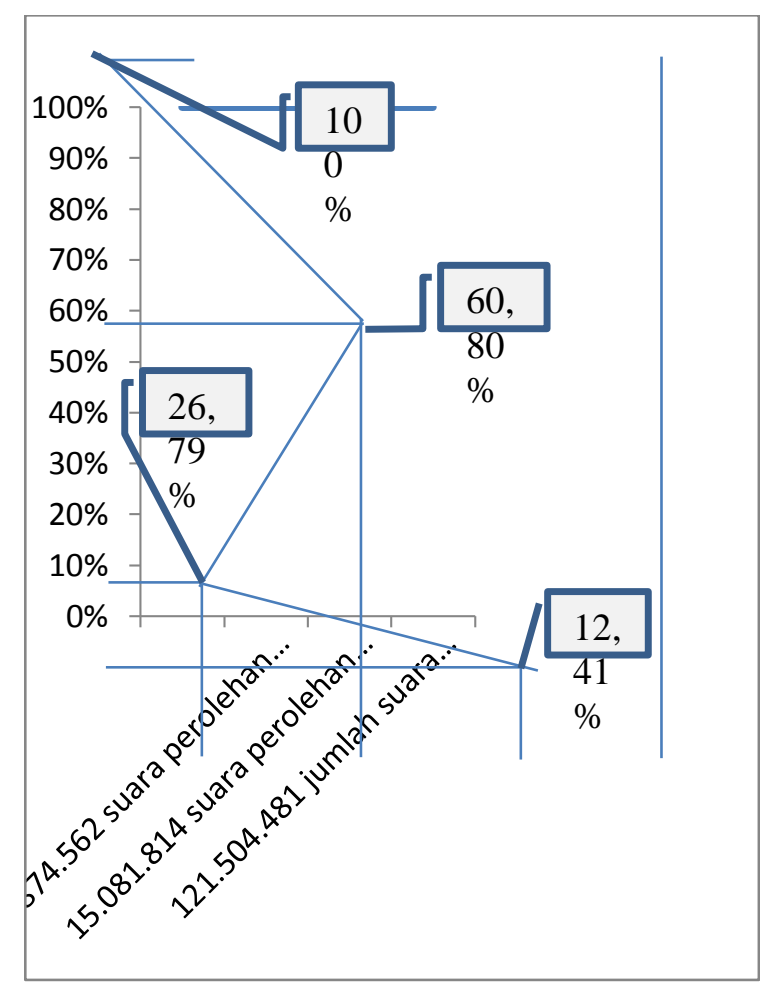

Gambar 2. Kurva 1 Hasil Suara dalam Pemilu Presiden dan Wakil Presiden 2009

\section{Pemilu Legislatif DPR Aceh 2009}

Gerakan Aceh Merdeka (GAM) telah membentuk Partai Lokal sendiri dengan nama Partai Aceh (PA) pada tahun 2008, dan akhirnya berhasil memenangkan Pemilu Legaslatif DPR Aceh, dengan menguasai 33 dari 69 kursi legislatif yang tersedia pada tahun 2009. Dengan perolehan suara PA mencapai 1.007.173 suara (47\%) sehingga mampu mendominasi DPRA dengan 33 kursi dari 69 kursi. Untuk tingkat DPRK, Partai Aceh memimpin kursi legislatif di 12 Kabupaten dari 23 Kabupaten/Kota.

Kemenangan yang diraih oleh Partai Aceh (PA) berlanjut hingga hanya menyisahkan satu kursi untuk Partai Daulat Aceh (PDA) sebagai pesaingnya ditingkat lokal dari lima pesaing PA ditingkat Provinsi Aceh dalam perebutan suara. Kemenangan PA dilevel DPRK, juga berlanjut 
hingga ke tingkat kabupaten dan kota di daerah itu.

PA meraih mayoritas suara di delapan kabupaten.

Misalnya di Aceh Besar (75\%), Pidie (95\%), Pidie Jaya (90\%), Bireuen (98\%), Aceh Utara (95\%), Lhokseumawe (97\%), Aceh Timur (90\%), Langsa (75\%), dan Aceh Tamiang (70\%). Selanjutnya Aceh Jaya (70\%), Aceh Barat (75\%), Nagan Raya (80\%), Aceh Barat Daya dan Aceh Selatan (75\%), Simulue (70\%), Singkil dan Subulussalam (65\%). Kemudian Aceh Tenggara (60\%), Aceh Tengah dan Bener Meriah (48\%), dan Gayo Lues (70\%).

\section{KESIMPULAN}

1) Dinamika politik di Aceh terjadi berawal dari konflik yang berakhir dengan jalan perundingan (negosiasi) yang juga dipengaruhi oleh kebijakan-kebijakan dari elit Pemerintah Pusat, Pemerintah Daerah, dan Dunia Internasional dalam menciptakan perdamaian pasca perdamaian di Aceh.

2) Tujuan kebijakan-kebijakan yaitu untuk ketertiban masyarakat, kesejahteraan masyarakat, dan tegaknya syariat Islam di Aceh secara kaffah melalui Undang-Undang Pemerintahan Aceh (UUPA) Nomor 11 tahun 2006.

3) Pada Pemilu Legislatif 2009 di Aceh terdapat 8 daerah pemilihan (dapil) untuk kawasan Bireuen, Bener Meriah, dan Aceh Tengah (dapil 4) dan kawasan Lhokseumawe dan Aceh Utara (dapil 5). Pada Pemilu Legislatif 2014 di Aceh sudah berubah menjadi 10 daerah pemilhan (dapil) untuk kawasan Bireuen (dapil 3), kawasan Bener Meriah dan
Aceh Tengah (dapil 4) serta kawasan Lhokseumawe dan Aceh Utara (dapil 5).

4) Terjadinya konflik di kawasan lintas timur, tengah, dan barat Aceh membuat masyarakat di daerah tersebut berada dalam kesengsaraan terutama di bidang perekonomian hal ini tidak terlepas dari konflik yang terjadi membuat masyarakat menjadi takut saat akan melakukan aktivitas sehari-hari dalam upaya mencari rezeki.

5) Penyelesaian terkait dengan korban konflik di Aceh melalui qanun komisi kebenaran dan rekonsiliasi di Aceh dapat memperbaiki tatanan nilai sosial masyarakat yang telah mengalami kelenturan dan trauma psikolgis perang yang berbekas dan mendalam serta sulit dipulihkan bagi korban konflik. Namun masih berbenturan dengan kebijakan pemerintah pusat.

6) Dengan adanya status otonomi khusus (otsus) dan pengelolaan dana bagi hasil sumber daya alam (minyak dan gas bumi) sebesar 70\% kepada Aceh, belum menciptakan kesejahteraan yang maksimal terhadap masyarakat baik kawasan lintas timur, tengah, dan barat Aceh.

7) Persaingan antar partai politik dianggap sebagai ajang yang dapat memilih serta menemukan pemimpin yang dapat menjadi idola masyarakat Aceh dalam membangun Aceh kearah yang lebih baik sekaligus mampu menyelesaikan persoalan-persoalan yang terjadi di Aceh. Persaingan kontestasi politik 2017 dalam bentuk pola koalisi. 


\section{JURNAL HUMANIORA}

\section{DAFTAR PUSTAKA}

Apter, David E. (1988). Pengantar Analisa Politik. Jakarta: Rajawali Pers.

Budiardjo, Miriam. (2008). Dasar-Dasar Ilmu Politik. Jakarta: PT. Gramedia Pustaka Utama. ISBN : 978-979-22-3494-7.

Damsar. (2012). Pengantar Sosiologi Politik. Jakarta: Kencana.

Denny J.A. (2004). Manuver Elit, Konflik dan Konservatisme Politik. Yogyakarta: LKIS. ISBN: 979-25- 52316.

Duverger, Maurice (2003). Sosiologi Politik. Jakarta: PT Raja Grafindo Persada.

Gaffar, Afan. (2004). Budaya Politik Indonesia. Yogyakarta: Pustaka Pelajar.

Gayo, Iwan. (2007). Buku Pintar Seri Senior. Jakarta Selatan: Pustaka Warga Negara. ISBN: 979-25-2181-X.

Hamid, Ahmad Farhan. (2008). Partai Politik Lokal di Aceh. Jakarta: Kemitraan.

Hardiman, F. Budi, et al. (2011). Empat Esai Etika Politik. Jakarta Pusat: www.srimulyani.net. ISBN: 9786029861402.

Ismail, Badruzzaman. (2008). Sistem Budaya Adat Aceh dalam Membangun Kesejahteraan (Nilai Sejarah dan Dinamika Kekinian). Banda Aceh: Majelis Adat Aceh (MAA) Provinsi Nanggroe Aceh Darussalam. ISBN: 978979-15533-5-3.

Lauer, Robert H. (2001). Perspektif Tentang Perubahan Sosial. Jakarta: PT. Rhineka Cipta. hlm. 102.

Lawang, Robert. (1994). Buku Materi Pokok Pengantar Sosiologi. Jakarta:
Universitas Terbuka.

Majalah Aceh Kita. (2005). Yang Dikagumi Yang Dikhianati. Agustus. ISSN: 18298427.

Narwoko, J. Dewi dan Suyanto, Bagong. (2004). Sosiologi Teks Pengantar dan Terapan. Jakarta: Kencana Prenada Media Group.

Nurcholis, Hanif. (2005). Teori dan Praktek Pemerintahan dan Otonomi Daerah. Jakarta: Grasindo.

Nurhasim, Moch, dkk. (2008). Aceh Baru: Tantangan Perdamaian dan Reintegrasi. Yoyakarta: Pustaka Pelajar.

O'leary, Brendan. (2000). "Ilmu Politik." Dalam Kupper, Adam dan Kupper, Jessica (ed). Ensiklopedi Ilmu-Ilmu Sosial. Terjemahan. Munandar, Haris, dkk. Jakarta: PT Raja Grafindo Persada.

Ritzer, George. (2004). Sosiologi Ilmu Pengetahuan Berparadigma Ganda. Jakarta: PT. Raja Grafindo Persada.

Setiadi, Elly M dan Kolip, Usman. (2011). Pengantar Sosiologi Pemahaman Fakta dan

Gejala Permasalahan Sosial: Teori, Aplikasi, dan Pemecahannya. Jakarta:

Kencana Prenada Media Group.

Soekanto, Soerjono. (1992). Sosiologi Suatu Pengantar. Jakarta: Rajawali Pers.

Sugeng HR. (2014). Rangkuman Pengetahuan Umum Lengkap (RPUL). Semarang: Aneka Ilmu. ISBN: 979-9029-84-8. Surbakti, Ramlan. (1992). Memahami Imu Politik. Jakarta: PT. Gramedia 
Widiasarana Indonesia.

Susan, Novri. (2009). Pengantar Sosiologi Konflik dan Isu-Isu Kontemporer. Jakarta: Kencana.

Syani, Abdul. (2012). Sosiologi Sistematika, Teori, dan Terapan. Jakarta: Bumi Aksara.

Tim Penyusun. (2008). Kamus Bahasa Indonesia. Jakarta: Pusat Bahasa. ISBN: 978- 979-689-779-1.

Usman, A. Rani. (2003). Sejarah Peradaban Aceh. Jakarta: Yayasan Obor Indonesia.

Soejadi. (2001). Pemberdayaan Masyarakat dan Upaya Pembebasan Kemiskinan. Yogyakarta: Philosophy Press.

Widjajanto, Andi dan Wardhani Artanti. (2008). Hubungan Intelijen Negara 1945- 2004. Jakarta: Pasivis.

Wijono (1993). Konflik Dalam Organisasi. Semarang: Satya Wacana. 